\title{
A short critical analysis of curricular paradigms involved in teaching the mother tongue
}

Horia Corcheș \& Mușata Bocoș 


\title{
A short critical analysis of curricular paradigms involved in teaching the mother tongue
}

\author{
Horia Corcheş ${ }^{a}$, Mușata Bocoș ${ }^{b}$ \\ ${ }^{a}$ Doctoral School "Educational, Reflection, Development", Babeș-Bolyai University, 7 Sindicatelor Street, Cluj-Napoca, 400029, Romania \\ ${ }^{b}$ Faculty of Psychology and Educational Sciences, Babeş-Bolyai University, 7 Sindicatelor Street, Cluj-Napoca, 400029, Romania
}

*Corresponding author: horiacorches@gmail.com

Abstract

Keywords:

competences, curricular paradigm, cultural or the historical model, the linguistic or aesthetic model, the social model, the model of the orientation towards the reader or the personal development
Over the past decades, the pedagogy of competences has become the main direction of research and design of the didactic approach in the European space. This direction places the entirety of the educational process under the sign of the direct connection between school, education and life experience. Against this background, Sigmund Ongstad, in his work, Research on Mother Tongue Education in a Comparative International Perspective, puts into circulation and explains the concept of curricular paradigm, which is taken up in the didactics of mother tongue in our country in order to delimit the historical stages of certain specific curricular visions, as well as their characteristics. Thus, it is possible to speak of four paradigms or curricular models: the cultural or historical model, the linguistic or aesthetic model, the social model and the model of the orientation towards the reader or the personal development. The cultural model aims at forming the national consciousness, the feeling of patriotism; it is centred on the teacher, it favours the dogmatic and the socratic methods, the teacher being the expert in transmitting information ex-chatedra. The social model favors the same methods: it is centred on the teacher and the student, but it aims at subsuming the literature of ideological goals. The aesthetic or linguistic model, also centred on the teacher and student, regards literature as an autonomous universe; within this model, the contents of learning are the structuralist instruments for deconstructing the text. The personal development model shifts the focus to the student, favours the active-participative methods and privileges the reflection on the set of values proposed by the world of text, but also the interpretation of the relationship between the world represented by the text and the world of the reader.
Zusammenfasung

\section{Schlüsselworte:}

Kompetenz,

Lehrplanparadigma,

kulturelles Modell,

ästhetisches Modell,

soziales Modell, as

Modell der

Orientierung am

Leser
In den letzten Jahrzehnten ist die Pädagogik der Kompetenzen zur Hauptrichtung der Forschung und Gestaltung des didaktischen Ansatzes im europäischen Raum geworden. Diese Ausrichtung stellt den gesamten Bildungsprozess in den direkten Zusammenhang zwischen Schule, Bildung und Lebenserfahrung. Vor diesem Hintergrund bringt Sigmund Ongstad in seiner Arbeit "Forschung zur Muttersprachenbildung in einer vergleichenden internationalen Perspektive" das Konzept des Lehrplanparadigmas in Umlauf, das in der Didaktik der Muttersprache in unserem Land aufgegriffen wird, um die historischen Stadien bestimmter curricularer Visionen, sowie deren Eigenschaften abzugrenzen. Man kann also von vier Paradigmen oder Lehrplänen sprechen: dem kulturellen oder historischen Modell, dem sprachlichen oder ästhetischen Modell, dem sozialen Modell und dem Modell der Orientierung am Leser oder der persönlichen Entwicklung. Das kulturelle Modell zielt darauf ab, das nationale Bewusstsein und das Gefühl des Patriotismus zu formen. Es konzentriert sich auf den Lehrer, es bevorzugt die dogmatischen und die sokratischen Methoden, wobei der Lehrer der Experte für die Übermittlung von Informationen ex-Chatedra ist. Das Sozialmodell bevorzugt die gleichen Methoden: es konzentriert sich auf den Lehrer und den Schüler, zielt jedoch darauf ab, die Literatur der ideologischen Ziele zu subsumieren. Das ästhetische oder sprachliche Modell, bei dem auch Lehrer und Schüler im Mittelpunkt stehen, betrachtet die Literatur als ein autonomes Universum. Innerhalb dieses Modells sind die Lerninhalte die strukturalistischen Instrumente zur Dekonstruktion des Textes. Das Persönlichkeitsentwicklungsmodell verlagert den Fokus auf den Schüler, bevorzugt die aktiv-partizipativen Methoden und bevorzugt die Reflexion über die von der Textwelt vorgeschlagene Wertemenge, aber auch die Interpretation der Beziehung zwischen der durch den Text dargestellten Welt und die Welt des Lesers.

\section{Introduction}

Throughout recent decades, specialists in pedagogy have won new battlegrounds, whose evolution is, in its turn, progressive and systematic (Chiş, 2015). It can be easily noticed that there are two great pedagogical periods, generically seen as distinct: a traditional one, and a second, modern one. While traditional pedagogy focused on knowledge, memory, and assimilated content, being characterised by superficial learning, modern pedagogy has evolved to favour critical thinking, problem solving, development and anticipation, thus leading to in- 
depth learning. New pedagogical paradigms propose a more specific definition of the concept, so that nowadays it is an ability-oriented type of pedagogy that we are referring to. This new pedagogy pays attention to both the nature and the content of the learning experience, to teacher-student relationships, as well as teacher-teacher and student-student relationships, understanding all of them in light of the direct connections between school, education and life experience (Bocoș \& Jucan, 2019).

Along with the theoretical development of these directions in pedagogical research, a growing interest has also been registered in establishing certain curricular patterns that could help circumscribe the specificity of such views on diachronic education in particular.

Coined by Sigmund Ongstad and detailed in his Research on Mother Tongue Education in a Comparative International Perspective (Ongstad et al., 2007), the notion of the curricular paradigm circumscribes especially those methods that determine the dominant teaching concept and the adjacent alternative concepts, as well as the evolution of the educational rhetoric regarding the mother tongue.

International Mother tongue Education Network (IMEN) was born out of the desire to compare modern research paths in the field of mother tongue learning, aiming at understanding various cultures' effort to assimilate the standard language in different countries (Ongstad et al., 2007). The aforementioned text, published in 2007, summarises the main theoretical principles and the methodological progress which served as the foundation of IMEN research during recent decades and which now broaden the scope of qualitative, comparative research in the field of mother tongue learning.

Initial conclusions have confirmed that the analytical role of the curricular paradigm can be easily highlighted amongst theorists, pedagogy and didactics specialists, whose perspectives on learning the mother tongue are rather homogeneous. It is, however, more difficult to prove the applicability of the same concept in other areas of mother tongue teaching, such as school curricula, textbooks, didactic auxiliary books and teaching per se, where theoretical concepts become dissipated, more and more diffuse, hindering one's ability to follow the thread of a coherent curricular vision. The more we near the level of actual teacher-student interaction, the more difficult it becomes to identify the paradigmatic concepts shared by the members of educational groups (Ongstad et al., 2007).

While attempting no actual analysis of these comparative studies, we do highlight their importance as a general intellectual context contributing to the appearance of concepts such as the curricular paradigm or the curricular model, which were later included in autochthonous research and helped configure the dominant specificity of teaching in various periods of time, observed diachronically until today.

\section{Curricular paradigms and their diachronic evolution}

In the $19^{\text {th }}$ and $20^{\text {th }}$ centuries, European schools managed to selectively exploit the formative purpose of reading and its potential for diversity, due to dynamic educational policies, as well as to continuous advances in reception theories.

Paradigmatically, there are four distinct teaching patterns, each associated with an overarching and recurrent perspective. Out of the autochthonous literature in this field, Florentina Sâmihăian (Sâmihăian, 2014) and Alina Pamfil (Pamfil, 2016) have explained these patterns; their theories are set apart through minor terminological differences.

Thus, while Florentina Sâmihăian draws a clear distinction between the cultural or historical model, the linguistic model, the social model and the personal development model, Alina Pamfil describes the cultural model, the aesthetic model, the social model and the same personal development model. Beyond any terminological technicalities, both authors operate with the same curricular paradigms, arranging them in a diachronic order whose pattern sequence is determined by the educational objectives of every specific historical moment.

In the Romanian educational sphere, these four paradigms have had a precise chronology: the cultural model was implemented in the second half of the $19^{\text {th }}$ century and in the first half of the $20^{\text {th }}$ century; the aesthetic model in the $80 \mathrm{~s}$ and the personal development model in the last decade, with an accentuated focus on its formative side within the last three years, as new school curricula for middle school were approved and established. 
The cultural model is the oldest one, based on the philosophy of the Enlightenment and aiming at one's knowledge of the national culture and of the national cultural space. Simultaneously, it is meant to enhance patriotism and national pride. The appearance of this model can be justified in relation to the birth of the national modern state, which involved the development of a national conscience and could use literature as a prime instrument. Obviously, the model relies on classical values such as good, truth and beauty and on a literary canon able to vouch for them. Therefore, canonical literary works must propose valid perspectives on perception (truth), must observe ethical norms (good) and must be representative for literature in general, through their expressive dimension (beauty) (Sâmihăian, 2014).

From the point of view of taught contents, the cultural model implies studying the complete works of representative authors, both their biography and bibliography, and their artistic universe; the process includes the writers' localisation in the dynamics of literary history and the analysis of symptomatic texts (Pamfil, 2016). In terms of didactic methodology, the teacher represents the centre of the educational process and favours dogmatic and Socratic methods, as an expert conveying information ex cathedra (Pamfil, 2016). Student assessment involves reproducing the received information, as performance indicators measure accuracy above anything else.

It must be said that, although the cultural model was born in and dominated the teaching practice of the second half of the $19^{\text {th }}$ century and the first half of the $20^{\text {th }}$ century, it did not disappear completely in the subsequent decades. In fact, it can still be found in our contemporary school system, more or less integrated in other models.

The partial abandonment of the cultural model was caused by the implementation of mass educational programs, which enhanced the diversity of the student body - with students from different social backgrounds and made an elitist approach impracticable. Another factor was the shift in politics, as the $50 \mathrm{~s}$ and $60 \mathrm{~s}$ were ruled exclusively through a socialist regime.

As for the social model, it could be argued that the Romanian phenomenon proceeded the correspondent European one, as the autochthonous social paradigm was imposed in the 50s and 60s, while Europe was generally acquainted to it only in the $70 \mathrm{~s}$ - and through other means, of course. The main objective of the model is the assimilation of certain images regarding the social structure of reality (Pamfil, 2016). However, while the European version prioritised the social conscience of its students, the Romanian model was submitted to a strong socialist ideology. Within the social model, literature became a discourse on society and social phenomena, decentralising the canon and replacing representative writers with those serving ideology. Therefore, a consequence of this paradigm in the Romanian educational system was the shaping of minds according to political and ideological objectives, associated with such concepts as the new man, the proletariat's fight, the communist society, bourgeoise decadence etc. Contextualisation dealt mostly with the social dimension and even classical texts were read through the prism of contemporary social issues. As opposed to its European brand, whose theoretical discourse focused on sociocriticism, feminism or multiculturalism, the Romanian social model only served the political ideology of the moment.

When it comes to pedagogical practice itself, this curricular model focuses on the student and on the teacher, who could guide a process of selective reading, in order to locate various ideological, political and social suggestions, especially the non-explicit ones. The dogmatic and Socratic methods are still favoured, but the student is encouraged to engage with the world of the text. Ideally, assessment should not target the informational dimension, but rather communication skills, argumentative abilities and eloquence in conveying ideas. However, because of political deviations, the Romanian educational system actually evaluated the reproduction of an ideological - and often cliché-ridden - discourse.

The third model - the aesthetic one (in Pamfil's terminology) or the linguistic one (in Sâmihăian's terminology) - appeared more explicitly in the Romanian teaching system of the $70 \mathrm{~s}$, alongside the social model. Generally speaking, this model is no longer centred on a sum of literary universes, belonging to a sequence of authors in literary history, but considers the text to be an autonomous universe, based on construction mechanisms to be deciphered only with the aid of specialised instruments. This is why the model is sometimes called an analytical one and is seen as different from the cultural or synthetic - one. The objective is the development of aesthetic taste or even the development of an aesthetic conscience (Sâmihăian, 2014). The central canon is not abandoned, but representative fragments will be chosen 
for studying, as learning is mostly oriented towards proper analysis (Pamfil, 2016). Although it would appear that aesthetic judgements can be easily formulated, deciding on the value of certain texts, inherent limitations endure, as the structuralist, hermeneutical and stylistically normative set of instruments remains the main theoretical discourse of the paradigm.

The advantage in comparison to the cultural model derives from the increased freedom of the student (the beneficiary of the learning process) inasmuch as his work is no longer reproductive and his contact with the text is direct. On the other hand, as Tzvetan Todorov (Todorov, 2011) argues, there is a risk of generalised technical and substance-void analysis, where the instrument becomes a formula, a cliché, and the student misses the profound meaning of the text (Sâmihăian, 2014).

From the point of view of didactic practice, this curricular model is centred on the teacher and on the student, with the former still being the expert in charge. Assessment tests the assimilation of a certain set of conceptual and analytical tools.

The curricular model of personal development (Pamfil, 2016) - the reader-oriented model (Sâmihăian, 2014) - only appeared in Europe in the last decade and was included almost simultaneously in the Romanian educational system. Its major goal is the complex personal development of students, highlighting the importance of global textual meaning and interpretation. Literature is thus seen as a discourse on humanity, on the human condition and on human nature (Pamfil, 2016). Therefore, the model prioritises reflection on the values represented in a work of literature, on inter-human relations, character evolution and the relationship between the fictional world and the reader's world. The educational process happens through exploring various fields of knowledge, through individual survey and reflection or through experimental discovery methods, leading to in-depth, meaningful learning (Chiș, 2005). The paradigm of personal development is based on the two main functions of the teacher: first, they will try to acquaint themselves with the students (documenting themselves on the students' interests, learning difficulties, literary preferences etc.); at the same time, they will attempt to help each student in their individual development process, charting their performance, providing feedback and constant support.
The specificity of this paradigm in relation to Romanian literature and language is granted by the accent placed on student benefits in terms of personal, social, cultural and academic development: students can reach a point of self-knowledge and can build a set of personal values based on their thoughts on literature and on their own learning methods; also, they can practice selfexpression through writing and speaking, conveying not just ideas, but also emotions; performance in the field of communication can enhance self-worth and selfconfidence; the student can gain a better understanding of other people and can more easily establish relationships with them within activities involving interaction and cooperation (discussions about the text, sharing opinions; role play, with the purpose of practicing oral communication strategies; choosing the right lexical and grammatical elements depending on the interlocutor; collective writing); students can better comprehend their own world, using both literary and non-literary materials (while reading the texts, they will reflect on personal experiences, practicing critical thinking); they can develop their creative potential, participating in activities belonging to different related disciplines; they will utilise language-related content in order to communicate clearly, correctly and in an adequate way in the given context, so that their intentions can have an impact on the listener; they can finally achieve better results in all disciplines, granted that they can manage oral and written communication techniques.

To summarise, this paradigm turns reading into a form of self-knowledge, which allows students to develop their awareness of the cognitive-emotional effects of the text and to experience the intellectual pleasure ensured by literature.

In terms of didactic methodology, this curricular model is centred on the student, favouring activeparticipatory methods. The teacher's role is to facilitate and to guide, and assessment - organised with more difficulty than in the case of other models - attempts to evaluate communication skills, argumentative abilities and eloquence.

\section{Conclusions}

Thus, from the point of view of educational science, the cultural model involves focusing on the teacher and using the dogmatic or Socratic methods. In addition, the social model is centred on the teacher and on the student, but makes use of the same methods, while the aesthetic 
model proposes activities centred on both the teacher and the student as well as active teaching methods (Bocoș, 2013). This transition started with the dominance of the dogmatic method, continued with stages favouring Socratic methods and ended with the supremacy of active methods. In reality, the discipline's evolution is not quite linear, and boundaries between various stages are actually less clear. These models have existed synchronically all throughout recent history. The vast majority of school curricula are heterogeneous, announcing both future patterns and the continuation of previous curricular trends, while pedagogical practice allows the intersection of methods and theoretical elements belonging to all four curricular models.

\section{Authors note:}

The authors have equal contributions to this article.

Horia Corcheș teaches Romanian language and literature at the George Bariţiu National College in Cluj-Napoca and is currently a doctoral student at Babeș-Bolyai University. He was a school inspector of Romanian language and literature for 12 years, and currently has the status of collaborator, as a trainer, of the New Horizons Foundation, but also of other institutions such as the Center for Independent Journalism. He has a permanent column in Dilema Veche magazine, where he writes articles on education. His research interests are oriented towards the didactics of reading, being concerned with the mechanisms by which reading identification is an essential stage in the process of understanding and interpreting the text, from the perspective of including said texts in the wider process of personal development. $\mathrm{He}$ is also concerned with the means by which non-formal education can intermingle, in the instructionaleducational process, with formal education.

Mușata Bocoş is University Professor and Ph.D. Coordinator at the Faculty of Psychology and Sciences of Education (Babeș-Bolyai University, Cluj-Napoca, Romania). She has obtained a Ph.D. in Educational Sciences in 1997 at Babeș-Bolyai University. Her research interests are reflected in a series of studies and articles published in important national and international journals. Her teaching activity covers several domains such as the theory and methodology of curriculum, general didactics, and educational research.

\section{References}

Bocoş, M.-D. (2013). Instruirea interactivă. Repere axiologice şi metodologice. Iaşi: Editura Polirom.

Bocoş, M., Jucan, D. (2019). Fundamentele pedagogiei. Teoria şi metodologia curriculumului. Repere şi instrumente didactice pentru formarea profesorilor, ediţia a IV-a, revizuită. Pitești: Editura Paralela 45.

Chiş, V. (2005). Pedagogia contemporană. Pedagogia pentru competențe. Cluj-Napoca: Editura Casa Cărții de Știință.

Ongstad, S., Herrlitz, W., Piet-Hein, V., (2007). Research on Mother Tongue Education in a Comparative International Perspective. New York: Editions Rodopi.

Pamfil, A. (2016). Didactica literaturii. Reorientări. București: Editura ART.

Sâmihăian, F. (2014). O didactică a limbii și literaturii române. București: Editura ART.

Todorov, T. (2011). Literatura în pericol, traducere din limba franceză şi postfaţă de Luigi Bambulea. București: Editura Art. 